Ministerstwo Nauki

i Szkolnictwa Wyższego

Digitalizacja archiwalnych numerów czasopisma naukowego Analecta Cracoviensia 1-24 (1969-1992)

i ich publikacja w otwartym dostępie - zadanie finansowane w ramach umowy 672/P-DUN/2017 ze środków

Ministra Nauki i Szkolnictwa Wyższego przeznaczonych na działalność upowszechniającą naukę

Bp BOLESEAW PYLAK

\title{
POWOKANIE LUDZI ŚWIECKICH W ŚWIETLE WYPOWIEDZI II SOBORU WATYKAŃSKIEGO
}

\section{STAN ZAGADNIENIA W TEOLOGII PRZEDSOBOROWEJ}

Słowo ,powołanie” jest terminem wieloznacznym. W języku potocznym posługujemy się nim często dla wyrażenia specjalnego szacunku dla przedstawicieli pewnych zawodów. Mówimy np., że to jest lekarz z powolania, nauczyciel lub ksiądz z powołania. Jest rzeczą charakterystyczną, że owo bliższe określenie ,z powołania” odnosi się zwykle do zawodów służących bezpośrednio dobru człowieka. W takim pojęciu powołania kryje się aprobata wartości humanistycznych i społecznych związanych z wywykonywaniem tych zawodów oraz uznanie dla osobistego zaangażowania się ich przedstawicieli w spełnianiu swoich obowiązków. O pracy ludzi w innych zawodach raczej nie mówimy jako o specjalnym powolaniu.

W pojęciu ,ksiądz z powołania” dostrzegamy ponadto jego wymiar teologiczny. Poprzez katechezę, kazania urobiliśmy w powszechnej świadomości naszych wiernych przekonanie, że praca księdza jest realizacją specjalnego wezwania Bożego do słuzby wiernym w Kościele. Natomiast kiedy mówimy o pracy ludzi świeckich i określamy ją przydawką ,z po-wołania", nie stwierdzamy tym samym jej bezpośredniego powiązania z Bogiem; używamy wówczas tego terminu w sensie tylko pochodnym, w znaczeniu pewnej analogii.

Fakt swoistego wyakcentowania powołania kapłańskiego w stosunku do innych zawodów tỉumaczy się między innymi dotychczasowym rozwojem eklezjologii, która zwłaszcza po Soborze Trydenckim podkreślała głównie element hierarchiczny w Kościele. Dlatego mieliśmy względnie dobrze rozwinięta teologię hierarchii, a prawie nic na temat teologii świeckich w Kościele. W takim układzie rzeczy nie było miejsca dla po- 
jęcia poẃołania laikatu i jego teologicznego wymiaru. Brak więc równomiernie rozwiniętej eklezjologii - to jedna z przyczyn dotychczasowego milczenia teologii na temat powołania ludzi świeckich.

Inną przyczyną tego stanu rzeczy był brak jasnych pojęć na temat tego, co dzisiaj oznaczamy mianem powołania chrześcijańskiego. Wprawdzie wypracowana przez wieki nauka o przeznaczeniu do zbawienia i potępienia (praedestinatio i reprobatio) zawierała prawdę o powołaniu ludzi do zbawienia, ukazywała ją jednak głównie od strony Boga jako decyzję Jego woli, nie zostawiając zbyt wiele miejsca dla odpowiedzi człowieka na ów zbawczy zew Boży. W oparciu o teksty biblijne z Listu do Efezjan $(1,5)$ i do Rzymian $(8,28 ; 30)$ mówiono o przeznaczeniu do łaski i chwały, wyliczano wszystkie akty, którymi Bóg prowadzi człowieka do zbawienia (,przejrzał, przeznaczył, wezwał, usprawiedliwił, uwielbił”), rozróżniano przeznaczenie pełne, ogarniające cel-zbawienie i środki prowadzące do niego oraz przeznaczenie cząstkowe, odnoszące się do jednego z elementów składowych procesu zbawczego (np. przeznaczenie do wiary lub łaski uświęcającej). Niewątpliwie w tych wszystkich wywodach mieści się prawda o powołaniu chrześcijańskim człowieka, jednak o jego roli w realizacji Bożego planu zbawienia mówiono raczej niewiele. Po prostu nie zwracano na to uwagi. Ponadto całe to zagadnienie rozpatrywano w skali jednostki powoływanej do zbawienia. Nie zwracano natomiast uwagi na fakt, że to zbawienie, aczkolwiek indywidualne, tyczące każdej osoby oddzielnie, dokonuje się z woli Bożej poprzez społeczność zbawiającą i w ramach wspólnoty zbawionych. Ściśle biorąc, tą właśnie wspólnota jest rzeczywistością uprzednią $\mathrm{w}$ stosunku do jednostki zbawianej. Człowiek zbawia się, włączając się $\mathrm{w}$ tę wspólnotę.

Dalszym brakiem, który uniemożliwiał pełniejszy rozwój teologii powołania ludzi świeckich w Kościele, było niedocenianie naturalnej wartości świata stworzonego, traktowanie go jako przeszkody $\mathrm{w}$ duchowym rozwoju człowieka. Negatywna ocena świata rodziła pokusę nieufności i ucieczki od niego. Postawę tego rodzaju dostrzegamy w dawnej ascezie monastycznej, którą często przenoszono w życie ludzi świeckich bez żadnych retuszy i prób dostosowania jej do innych warunków ich życia. Stąd $\mathrm{w}$ świadomości i życiu wielu $\mathrm{z}$ nich stwierdzamy brak powiązania a nawet szkodliwy rozdział między tym, co Boże i tym, co ludzkie. Dawna teologia nie dawała podstaw do korekty takich poglądów, gdyż nie określała jasno relacji Kościoła do świata.

Teologia przedsoborowa i soborowa wniosła $\mathrm{w}$ ten stan rzeczy przeogromne zmiany. Najpierw zainteresowano się teologią rzeczywistości ziemskich; dostrzeżono ich naturalne wartości. W świetle objawienia Bożego określono relację i posłannictwo Kościoła wobec świata. W ramach rozwijającej się eklezjologii ustalono ,status" teologiczny laikatu, ozna- 
czono jego miejsce i rolę w Kościele oraz udział w realizacji zbawczych planów Boga wobec świata.

Ponadto nauka ostatniego Soboru o powołaniu ludzi świeckich dużo zawdzięcza personalizmowi filozoficznemu, który wprowadzony do teologii wniósł bardzo wiele, zwłaszcza w wyjaśnianie tajemnicy wiary, laski i w sakramentologii. Ujmowanie powołania w kategoriach personalnych ustawia to zagadnienie jako relację między osobowym Bogiem, który oferuje zbawienie i osobą-człowiekiem, który je akceptuje i realizuje, współdziałając ze zbawiającym Bogiem. Rozpatrywanie osoby i jej celów życiowych w ramach wspólnoty osób w Kościele stworzyło społecznokościelne tło dla omawianego przez nas zagadnienia.

Dużo też światła w interesującą nas sprawę powołania laikatu wriosła teologia biblijna, której prawdziwy renesans przeżywamy w ostatnich latach.

Powyższy rzut oka na przeszłość omawianego zagadnienia odsłania nam jego korzenie i ułatwia zrozumienie aktualnego stanu wiedzy teologicznej o nim. W rozwój tej wiedzy wniósł dużo ostatni Sobór. Zwłaszcza jego nauka o powołaniu chrześcijańskim okazała się bardzo płodną dla prawdy o specjalnym powołaniu ludzi świeckich. Stanowi bowiem dla niego nieodzowny fundament. Co więcej, jest nawet jego wewnętrznym tworzywem. Dlatego nie możemy pominąć tego zagadnienia przy omawianiu wspólnotowego charakteru powołania ludzi świeckich w Kościele.

\section{POWOEANIE DO CHRZEŚCIJAŃSTWA - FUNDAMENTEM \\ I UKORONOWANIEM WSZYSTKICH POWOEAŃ SZCZEGOEOWYCH}

W Konstytucji Gaudium et spes odnajdujemy nakreślony boski plan zbawienia, w którym człowiek zajmuje bardzo poczesne miejsce. Bóg Stwórca powołuje go do uczestnictwa w swoim życiu, zaprasza do rozmowy, trwałej więzi i wspólnoty z sobą; pragnie dzielić się z nim swoim szczęściem ${ }^{1}$. Bliskość tego rodzaju suponuje fakt przebywania obu stron w jednym świecie życia osobowego. Dlatego Bóg wynosi człowieka w sferę swojego życia, czyni go mocą łaski i traktuje jako syna ${ }^{2}$. To stanowi o osobliwej godności chrześcijanina.

Boża nobilitacja człowieka stała się możliwa dzięki uczłowieczeniu Syna Bożego, który nie tracąc bytu Bożego, zstąpił w ludzkość, by ją uwolnić od zła i wynieść na piedestał rodziny dzieci Bożych. Kontakt z Chrystusem, uczestnictwo w Jego zasługach jest koniecznym warunkiem owego wyniesienia człowieka w świat Bożej rzeczywistości. Ponieważ Chrystus uwielbiony w swoim człowieczeństwie stał się nam bez-

1 Por. nr 18, 19, 21.

2 Tamże, nr 21. 
pośrednio niedostępny, dlatego ustanowił widzialny Kościół, który Go uobecnia i w ten sposób czyni możliwym zbawczy z Nim kontakt 3 .

Tak w wielkim skrócie przedstawia się boski plan zbawienia i zbawcza oferta Boga wobec nas, którą określamy mianem powołania chrześcijańskiego. Bóg umożliwia nam jego realizację poprzez osobowe zjednoczenie z Chrystusem obecnym i działającym w Jego widzialnym Kościele. Wejście zatem w Kościół, uczestnictwo w jego życiu jest obowiązkiem, wynikającym z przyjętego powołania chrześcijańskiego.

Ostatni Sobór bardzo mocno akcentuje prymat wspólnoty w realizacji zbawczych planów Boga. Bóg bowiem postanowił ,uświęcać i zbawiać ludzi nie pojedyńczo..., lecz uczynić z nich lud, który by Go poznawal w prawdzie i święcie Mu służył" - czytamy w Lumen gentium ${ }^{4}$. Dlatego powołał najpierw naród izraelski, wszedł z nim w przymierze i zlecił mu przygotowanie drogi zbawienia. Następnie Chrystus ustanowił nowy lud Boży jako kontynuację poprzedniego; stał się jego Głową. Odtąd w ramach tylko tegoż ludu Bożego - Kościoła możemy osiągnąć zbawienie.

Członkami ludu Bożego stajemy się mocą sakramentu chrztu i bierzmowania. Chrzest włącza nas w Kościół i dokonuje inkorporacji w Chrystusa. Dzięki temu stajemy się podobni do Niego ${ }^{5}$, uczestniczymy w Jego zasługach, otrzymujemy pewne uzdolnienia i uprawnienia nadprzyrodzone do współdziałania z Nim w realizacji Bożego planu zbawienia. Teologia określiła je mianem uczestnictwa w trzech urzędach - funkcjach Chrystusa: do uświęcenia, nauczania i rządzenia.

Bierzmowanie, drugi sakrament inicjaçji chrześcijańskiej, dopełnia chrzest, pogłębia więź jedności z Kościołem, zapewnia szczególną moc Ducha Swiętego, czyni przyjmujących go dojrzałymi chrześcijanami, powolanymi do büdowania Królestwa Bożego na ziemi ${ }^{6}$.

Oba sakramenty, chrzest i bierzmowanie, stając się udziałem wszystkich czlonków Kościoła, stanowią o ich równej godności chrześcijańskiej w obliczu Boga ${ }^{7}$. Przez nie realizujemy nasze wspólne powołanie chrześcijańskie w jego wymiarze statycznym, tzn. mocą powyższych sakramentów stajemy się ontycznie pełnoprawnymi członkami ludu Bożego, związanymi z Chrystusem jako Pośrednikiem między Bogiem i ludźmi i naszym Zloawcą. Nie jest to jednak jedyny wymiar powołania chrześcijańskiego. Stając się bowiem członkami Kościola zaciągany zobowiązanie do współdziałania z Chrystusem w budowaniu Królestwa Bożego. Powołanie chrześcijańskie jest zawsze powołaniem do działania, do apo-

3 Tamże.

Nr 9.

Dekret o ekumeniźmie, nr 22.

Lumen gentium, nr 33; Dekret o działalności misyjnej Kościoła, nr 36.

- Lumen gentium, nr 32. 
stołowania. Cały też Kościół z natury swojej ukierunkowany jest ku temu apostołowaniu, tzn. ku realizacji zbawczych planów Boga wobec ludzkości i świata. Działa on w tym wypadku poprzez swoich wiernych. Działanie to bywa wielorakie. Dlatego różni członkowie Kościoła otrzymują rozmaite $\mathrm{ku}$ temu uzdolnienia nadprzyrodzone i różne funkcje do spełnienia. Dopiero na tej płaszczyźnie swoistego dynamizmu Kościoła dokonuje się podział jego członków na stan ludzi świeckich oraz na stan kapłański. Przedstawiciele tego drugiego stanu mocą święceń kapkańskich otrzymuja specjalne lizdolnienia nadprzyrodzone i uprawnienia do dzłałania na rzecz pozostałych członków Kościoła. Służą im swoim nauczaniem i posługa kapłańską. Sprawa ich powołania do tej służby to odrębny temat, nie mieszczący się $w$ ramach omawianego przez nas zagadnienia.

Natomiast świeckich chrześcijan Bóg powołuje do innych zadań. Można je uszeregować w pewne grupy, wykorzystując sugestię zawartą w soborowym określeniu laikatu. Ojcowie Soboru głoszą, że pod nazwą świeckich rozumie się w Konstytucji „wiernych chrześcijan, którzy jako wcieleni przez chrzest w Chrystusa, ustanowieni jako lud Boży i uczestniczący na swój sposób (suo modo) w kapłańskim, prorockim i królewskim urzędzie Chrystusa, biorą udział w zakresie sobie właściwym (pro parte sua) w posłannictwie całego ludu chrześcijańskiego w Kościele i w świecie" 8 .

W powyższej opisowej definicji laikatu podkreślono dwa momenty, które wyróżniają świeckich spośród innych członków Kościoła. Są nimi specyficzny sposób ich uczestnictwa w trojakim urzędzie Chrystusa (suo modo) oraz im tylko właściwy teren działania w Kościele i świecie (pro parte sua). Pierwszy moment nawiązuje do pewnych właściwości ontyczno-funkcjonalnych ludzi świeckich; drugi uwzględnia pole ich pracy apostolskiej. Oba momenty pozostają w stosunku do siebie w relacji wspóizależności. Uczestnictwo w trzech urzędach czy też funkcja Chrystusa rodzi w członkach Kościoła pewne uzdolnienia i uprawnienia do działania na rzecz całej zbawianej ludzkości. Dzięki nim Kościół, a ściśle biorąc Chrystus w Kościele, może posługiwać się poszczególnymi ludźmi w wypełnianiu określonych zadań zbawczych. Stają się oni stosownymi narzędziami w ręku działającego w Kościele Chrystusa.

Istnieje pewna analogia między działaniem Kościoła i aktywnością człowieka. Tak jak człowiek osiąga swoje cele poprzez działanie poszczególnych organów, tak Kościół realizuje swoje przeznaczenie poprzez działalność poszczególnych członków. Świeccy katolicy, uczestnicząc w trojakim urzędzie Chrystusa, uobecniają Go w świecie stworzonym, w którym

8 Tamże, nr 31; tłum. moje; przekład polski oficjalny nie odtwarza w pełni myśli tekstu łacińskiego. 
żyją i pracują jało chrześcijanie. Do tego zadania powołuje ich Chrystus, dając im ku temu stosowne moce i uprawnienia, i włączając ich mocą chrztu i bierzmowania w swój Kościół.

W świetle powyższych rozważań na temat relacji, jaka zachodzi między uczestnictwem ludzi świeckich w trojakim urzędzie Chrystusa i terenem ich działania apostolskiego, dostrzegamy bardziej wyraźnie wspólnotowy charakter ich powołania chrześcijańskiego. Świeccy stanowią integralną część organizmu Kościoła. Jako jego członkowie powołani są do wypełniania określonych zadań. Czynią to jako cząstki całości, jako narządy jednego społeczno-kościelnego organizmu. Ściśle biorąc, to Kościół, a właściwie Chrystus w Kościele działa przez nich jako swoje narzędzia. Działalność ich jest zatem przejawem i wyrazem aktywności całego organizmu Kościoła.

Zadaniem Kościoła jest uobecnianie Chrystusa-Zbawcy wśród ludzi i dla ludzi. Funkcję tę określamy mianem pośrednictwa zbawczego. Zmierza ono ku procesowi zbawczemu, który dokonuje się $\mathrm{w}$ duszy ludzkiej. $\mathrm{Na}$ tej drodze czlowiek rozwija swoją osobowość na miarę planów Bożych, osiąga doskonałość i jej ukoronowanie w postaci daru zbawienia. Wszystko to dzieje się w ramach ludu Bożego, który jako całość, doskonaląc poszczególnych ludzi, przyczynia się do rozwoju i postępu moralnego całej ludzkości. Poprzez tak uformowanych ludzi Kościół ulepsza wszystkie instytucje ludzkie i doskonali świat, wciągając w ten proces także świat rzeczy materialnych. Cały kowiem świat jest dziełem Boga Stwórcy i Odkupiciela. Człowiek poprzez swoje grzechy wprowadza weń nieład i dysharmonię. Dlatego „,całe stworzenie wzdycha i aż dotychczas rodzi w boleści" - głosi św. Paweł (Rz 8, 22). Odrodzony mocą łaski człowiek ma przywracać mu pierwotną doskonałość. Dzięki jego działaniu będzie ono kiedyś „wyzwolone z niewoli skażenia na wolność chwały synów Bożych” $(\mathrm{Rz}$ 8, 21).

W perspektywie tak widzianego celu świata, ludzkości i poszczególnych ludzi dostrzegamy lepiej omawiany wspólnotowy aspekt powołania ludzi świeckich w Kościele. Działają oni jako cząstki wspólnoty Kościoła, realizując jego całościowe posłannictwo. Celem tegoż działania jest również wspólnotowe dobro, w którym owa ludzkość żyje. W ramach więc działania wspólnoty zbawiającej i zmierzającej ku wspólnocie zbawionych mieści się powołanie chrześcijańskie wszystkich członków Kościoła, także ludzi świeckich. U tych ostatnich przybiera ono różne formy powołań szczegółowych, w zależności od pola ich pracy i zadań życiowych. Celem ich jest uświęcanie tych dziedzin życia i świata, w których żyją i działają jako chrześcijanie.

Odczytanie swojego powołania szczegółowego w tak widzianej perspektywie posłannictwa całego Kościoła jest nieraz trudne. Jeszcze trud- 
niejszą rzeczą jest jego praktyczna realizacja. Przy pomocy Bożej można jednak odnaleźć swoją drogę życia i być jej wiernym, gdyż Bóg powołując człowieka do określonych zadań, udziela mu równocześnie stosownych mocy do ich wypełnienia.

Dotychczasowe wywody umożliwiły nam pewnego rodzaju ,lokalizację" teologiczną ludzi świeckich w Kościele i oznaczenie ich roli w realizacji Bożego planu zbawienia. W oparciu o nie spróbujmy obecnie rzucić okiem na teren ich działania i konkretne zadania, jakie wyznacza im ich powołanie chrześcijańskie. Przybiera ono w ich życiu formę konkretnych powołań szczegółowych.

\section{UOBECNIANIE KOŚCIOŁA W ŚWIECIE I JEGO USWIĘCANIE - ZADANIEM SWIECKICH CZŁONKOW LUDU BOŻEGO}

„Zadaniem ludzi świeckich, z tytułu właściwego im powołania, jest szukać Królestwa Bożego, zajmując się sprawami świeckimi i kierując nimi po myśli Bożej" - czytamy w Lumen gentium ${ }^{9}$. Zadanie to określono mianem „vocatio propria” w odróżnieniu od powołania kapłańskiego czy zakonnego. W świetle powyższego stwierdzenia świeccy mają formować świat rzeczy doczesnych, w którym żyją, według wymagań ewangelii 10; winni go uświęcać, działając w nim jako chrześcijanie ${ }^{11}$.

Consecratio mundi - uświęcanie świata przez świeckich należy rozumieć $\mathrm{w}$ świetle wypowiedzi ostatniego Soboru jako przenikanie świata wartościami chrześcijańskimi ${ }^{12}$. Inaczej mówiąc, idzie w tym wypadku o chrystianizację świata doczesnego, o wiązanie go z Bogiem Stwórcą i Odkupicielem, o budowanie Królestwa Bożego, zajmując się sprawami świata ziemskiego. „Czym dusza jest w ciele, tym niechaj będą w świecie chrześcijanie" - głoszą Ojcowie Soboru za autorem listu do Diogeneta ${ }^{13}$. Dzięki działaniu świeckich Kościół staje się sakramentem zbawienia dla świata; ukazuje bowiem i zarazem realizuje tajemnicę miłości Boga do człowieka ${ }^{14}$.

Uświęcania świata dokonują świeccy na różnych odcinkach swojego życia. Mocą uczestnictwa w kapłaństwie Chrystusa całe ich życie, ukierunkowane ku Bogu, ma wartość zbawczej ofiary. „Wszystkie bowiem ich uczynki, modlitwy i apostolskie przedsięwzięcia, życie małżeńskie i rodzinne, codzienna praca, wypoczynek ducha i ciała, jeśli odbywają się w Duchu, a nawet utrapienia życia, jeśli cierpliwie są znoszone, stają się duchowymi ofiarami miłymi Bogu przez Jezusa Chrystusa" - czytamy

\footnotetext{
9 Nr 31.

10 Tamże, nr 31.

11 Tamże, nr 33 i 34.

12 Gaudium et spes, nr 43.

13 Lumen gentium, nr 38.

14 Gaudium et spes, nr 45.
} 
w Lumen gentium ${ }^{15}$. I tak jak w żyeiu Chrystusa, Najwyższego Kapłana, całe Jego życie miało wartość zbawczą, ale ukoronowaniem jego i szczytem była ofiara Krzyża, tak i w życiu świeckich - ofiary ich życia „składane są zbożnie Ojcu w eucharystycznym obrzędzie wraz z ofiarą Ciała Paniskiego" ${ }^{16}$. Ojcowie Soboru głoszą, że wierni ,na mocy swego królewskiego kapłaństwa współdziałają w ofiarowaniu Eucharystii; pełnią też to kapłaństwo przez przyjmowanie sakramentów, modlitwę i dziękczynienie, świadectwo życia świątobliwego, zaparcie się siebie i czynną miIość" 17. Wiemy też, że świeccy moca swojeđo kaołańsłva powszechnego moga w nadzwyezajnych okolicznościach udzielać chrztu, małżonkowie zaś są szafarzami sakramentu małżeństwa.

Funkcje kapłańskie spełniają świeccy także w życiu małżeńskim i rodzinnym. Sobór nie waha się nazywać rodziny „domowym sanktuarium Kościoła” ${ }^{18}$. Dlatego ,chrześcijańscy małżonkowie są dla siebie nawzajem, dla swoich dzieci i innych domowników wspólpracownikami łaski i świadkami wiary. Oni są pierwszymi zwiasturami wiary i wychowania swych dzieci; słowem i przykładem przysposabiaja je do życia chrześcijańskiego i apostolskiegc" 19.

Powołanie świeckich ujawnia się także w ich uczestnictwie w profetycznej funkcji Chrystusa. Chrystus naucza „nie tylko przez hierarchię... aie także przez świeckich" 20 . Głoszą oni ewangelię - raふ̇osną nowinę zbavienia swoim życiem chrześcijańskim, następnie słowem ${ }^{21}$, zarówno w życiu małżeńsko-rodzinnym, jak i zawodowym, społecznym. W rodzinie bowiem są „dia siebie nawzajem i dila swoich dzieci świadkami wiary i milości Chrystusowej" 22. W życiu społecznym głoszą Chrystusa swoją postawa chrześcijańską wobec spraw świata doczesnego i rozwiązywaniem jego problemów w duchu ewangelii ${ }^{23}$. Wyposażeni w nadprzyrodzony zmysł wiary są także świeccy nosicielami nieomylności wiary Kościola 24.

Uczestnicząc w trzeciej władzy Chrystusa, w Jego funkcji królewskiej, świeccy pełnią swoje specjalne powołanie, zwyciężając w sobie „władztwo grzechu" 25. Przezwyciężają go także w swoim środowisku, uzdrawiając „,istniejące na świecie urządzenia i warunki, jeśli one gdzieś skłaniaja do grzechu" 26. Ponadto poprzez służbę Chrystusowi w bliźnich budują

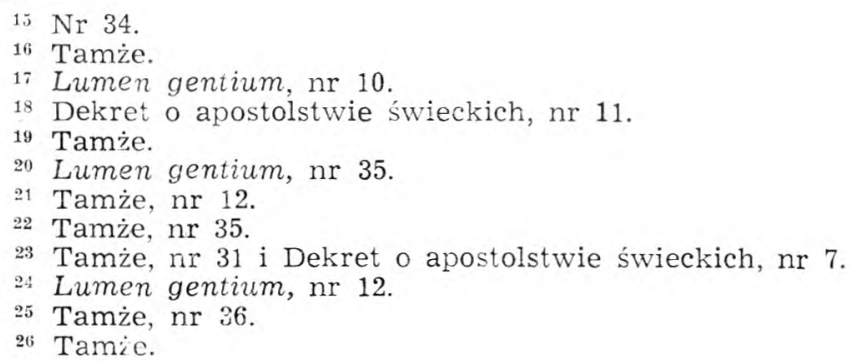


Jego Królestwo prawdy i życia, świętości i łaski, sprawiedliwości, miłości i polroju ${ }^{27}$. W skali społecznej świeccy chrześcijanie ujawniają swoją królewską godność Chrystusową, rozwijając naukę, technikę, cywilizację, przekształcając świat i podporządkowując go dobru człowieka. W ramach więc chrześcijańskiego uświęcania świata dokonują także jego swoistej humanizacji. Ponieważ Chrystus Król wyraźnie powiedział, że przyszedł na świat nie po to, by mu służono, lecz by służyć, tak samo Kościół, a zatem i jego świeccy członkowie swoją królewską godność, płynącą z Chrystusa, ujawniają w formie służenia światu i jego potrzebom 28 .

Z powyższych stwierdzeń wynika, że świeccy wierni, uczestniczący w trojakim urzędzie Chrystusa, realizują swoje powołanie przez obecność i chrześcijańskie działanie w świecie. Swiat i wymogi jego życia modyfiku.ją w swoisty sposób ich powołanie do chrześcijaństwa. Tym różnią się od innych członków Kościoła, zwåaszcza od stanu kapłańskiego. Wprawdzie dzielą z nimi wspólną godność chrześcijańską, budują jedno Królestwo Boże, czynią to jednak w sobie tylko właściwy sposób i w dziedzinach życia, które reprezentują ${ }^{29}$. Sa nimi: życie małżeńskie i rodzinne, kultura w różnych swoich przejawach, sztuka, sprawy gospodarcze, praca zawodowa, instytucje polityczne i stosunki międzynarodowe ${ }^{30}$. Obecność świeckich chrześcijan w tych dziedzinach życia ludzkiego jest szczególna i ich działalność apostolska bezwzględnie konieczna ${ }^{31}$. „Bez nich apostolstwo samych pasterzy nie może zwykle być w pełni skuteczne" podkreślają Ojcowie Soboru ${ }^{32}$. Żyłąc w świecie i formując go według myśli Bożej realizują oni w ten sposób swoje powołanie szczególowe, które jest ucieleśnioną, konkretną formą ich powołania chrześcijańskiego. Bóg powołując ich do uczestnictwa w swoim życiu, do godności dzieci Bożych, wciąga ich $\mathrm{w}$ realizację swoich planów zbawczych w stosunki do całego świata. W formie powołań osobistych, szczegółowo wyznacza im drogę, na której służąc innym i światu mają doskonalić swoją osobowość na miarę myśli Bożej. Proces ten zmierza ku pełni szczęścia w ramach eschatologii jednostkowej i ogólnej całego świata.

W perspektywie tak widzianej przyszłości świata i człowieka lepiej rozumiemy sens i znaczenie szczegółowych powołań ludzi świeckich. Mieszezą się one w ramach calości ich powolania chrześcijańskiego; są mu podporządkowane jako nieodzowny środek i warunek do osiągnięcia ostatecznego celu. Dlatego tak ważną rzeczą jest odczytanie swojego powołania życiowego i jego realizacja. Spełniając bowiem swoje obowiązki w ży-

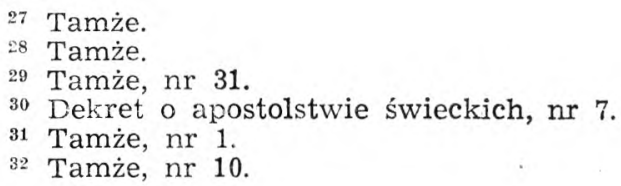


ciu małżenskim, rodzinnym, zawodowym ludzie świeccy tą właśnie drogą zmierzają ku zbawieniu, w skali zaś społecznej przyczyniają się do doskonalenia świata, ułatwiając $\mathrm{w}$ ten sposób zbawienie innym.

$\mathrm{Z}$ różnych powołań szczegółowych ostatni Sobór eksponuje specjalne powołanie do małżeństwa i życia rodzinnego, podkreślając jego wielkie znaczenie dla życia poszczególnych ludzi i całej społeczności ludzkiej. Rodzina jest „pierwszą i żywotną komórką społeczeństwa” ${ }^{33}$; jest „szkołą bogatszego człowieczeństwa" ${ }^{34}$; zdrowie osoby i społeczności ludzkiej oraz chrześcijańskiej wiąże się ściśle z pomyślną sytuacją wspólnoty małżeńskiej i rodzinnej" ${ }^{35}$ - czytamy w dokumentach soborowych.

Chrystus wspiera małżeństwo, ustanawiając specjalny sakrament, który „umacnia i jakby konsekruje małżonków chrześcijańskich do obowiązków i godności ich stanu; wypełniając mocą tego sakramentu swoje zadania małżeńskie i rodzinne..., zbliżają się małżonkowie coraz bardziej do osiągnięcia własnej doskonałości i obopólnego uświęcenia" 36 . Inaczej mówiąc, małżonkowie spełniając obowiązki swojego stanu, realizują $\mathrm{w}$ ten sposób swoje powołanie chrześcijańskie. Małżeństwo zatem nie jest instytucją uwarunkowaną tylko specjalną strukturą natury ludzkiej; jest ponadto zadaniem i obowiązkiem dla tych, których 'Bóg wzywa, aby na tej drodze życia zmierzali ku zbawieniu wiecznemu.

$\mathrm{Z}$ innych powołań szczegółowych warto jeszcze podkreślić wagę i znaczenie powołania do wykonywania poszczególnych zawodów świeckich. Powołania takie istnieją $\mathrm{i}$ one to nadają pracy ludzkiej swoisty walor Boży. Dzięki temu praca ta nie jest tylko zdobywaniem przysłowiowego kawałka chleba. Głębiej patrząc w jej istotę, jest ona w pierwszym rzędzie współdziałaniem człowieka z Bogiem w doskonaleniu rzeczy stworzonych; jest budowaniem lepszego świata, by był stosownym środowiskiem dla człowieka, umożliwiającym mu realizację jego osobistych i społecznych zadań. Chrześcijanie „swoją pracą rozwijają dzieło Stwórcy, zaradzają potrzebom swoich braci i osobistym wkładem przyczyniają się do tego, by w historii spełniał się zamysł Boży" - czytamy w Konstytucji Gaudium et spes ${ }^{37}$. Trud pracy związany z jej wykonywaniem jest formą ofiary, którą świeccy mocą swojego kapłaństwa składają Bogu, zwłaszcza w czasie ofiary eucharystycznej. W ten sposób uświecają oni całe swoje życie, łącznie z pracą zawodową, która jest także służbą Bożą, zasługującą na nagrodę wieczną.

Powyższe stwierdzenia ukazują nam teologiczny wymiar pracy zawodowej. Jest ona współdziałaniem w realizacji Bożego planu stworzenia;

\footnotetext{
33 Tamże, nr 11.

34 Gaudium et spes, nr 52.

35 Tamże, nr 47.

36 Tamże, nr 48.

$37 \mathrm{Nr} 34$.
} 
stanowi zadanie, do którego wykonania zaprasza i powołuje Bóg. Posłuszeństwo temu wezwaniu i wierność w spełnianiu obowiązków zawodowych zasługują — jak powiedzieliśmy - na zapłatę $\mathrm{w}$ niebie. $\mathrm{W}$ ten sposób każe nam patrzeć na pracę zawodową i wartościować ją teologia jako rzecznik objawienia Bożego. Nie jest to jednak jedyny punkt widzenia w rozpatrywaniu zagadnienia powołania człowieka do pracy zawodowej. Sprawą tą interesują się przedstawiciele także innych nauk, zwłaszcza psychologii i socjologii. Wyniki ich badań pokrywają się w całej pełni z tym, co mówi na ten temat teologia. Jeśli bowiem człowiek odczyta dobrze swoje powołanie i w pracy zawodowej jest na swoim miejscu, wówczas trud, związany nieodłącznie z wykonywaniem każdego zawodu, przestaje być ciężarem; może nawet stać się radością w myśl augustyńskiego powiedzenia: quod amatur, aut non laboratur, aut et labor amatur ${ }^{38}$. Wówczas praca przynosi też korzystne owoce.

Fakt, że wielu ludzi wykonuje zawód inny niż wyuczony, świadczy o uprzednim braku rozeznania własnej drogi życia. Podobnie zmiany zawodu już w trakcie jego wykonywania, co jest zjawiskiem ujemnym dla życia społeczno-gospodarczego, sygnalizują przykre pomyłki życiowe i brak wcześniejszej refleksji na temat swojego powołania zawodowego. Brakom tym i potrzebom wychodzą naprzeciw różnego rodzaju badania psycho-techniczne, które ułatwiają wybór właściwego zawodu na miarę wrodzonych uzdolnień i zamiłowan. Wyniki pracy $w$ tej dziedzinie ze strony psychologów i socjologów mogą okazać się pożyteczne, o ile korzystający z niej człowiek będzie kierował się w szukaniu dla siebie stosownego zawodu przede wszystkim motywem pełnienia woli Bożej, ujawnionej w jego strukturze psycho-fizycznej. Patrzenie bowiem i wartościowanie powołania zawodowego przez pryzmat objawienia Bożego umożliwia podjęcie najlepszego wyboru, opartego o najpełniejsze poznanie natury ludzkiej. Teologia w tym wypadku jest bardzo pomocna człowiekowi i ma ogromne znaczenie praktyczne.

Zestawiając powołanie ludzi świeckich w Kościele z powołaniami do stanu kapłańskiego i zakonnego, dostrzegamy względnie jasno dzielące ich różnice. Są to różne drogi życia, prowadzące jednak ku temu samemu celowi. Graficznie można by je przedstawić w formie trzech równoległych linii, wpisanych w jedną większą całość. Całością tą jest Lud Boży, złożony $\mathrm{z}$ powyższych trzech stanów, powołany do chrześcijaństwa, tzn. do pełnego zjednoczenia $z$ osobowym Bogiem. Lud ten realizuje swoje powołanie, współdziałając z Bogiem w zbawieniu całej ludzkości i całego świata. Każdy członek tegoż ludu ma w tym dziele zbawczym swoje miejsce i swoją rolę do spełnienia. Wezwanie do tego dzieła nazywamy powołaniem szczegółowym. Wszyscy to powołanie otrzymujemy, zarówno

3s De bono viduitatis, PL 40, 447-8. 
duchowni jak i świeccy; wszyscy jesteśmy powołani do budowania Królestwa Bożego, aczkolwiek na różnych odcinkach i stanowiskach tej wspólnej budowli. Spełniając obowiązki wynikające z powołań szczególowych, urzeczywistniamy $w$ ten sposób Boży plan zbawienia, tzn. realizujemy nasze powołanie do chrześcijaństwa w skali jednostkowej i spoleczno-kościelnej. Powołania szczegółowe wpisane są w całość tego dzieła; stanowią ważną jego składową i nieodzowny środek do uzyskania ostatecznego celu. Jest nim -- jak wiemy - z objawienia Bożego - pcłnia życia i szczęścia, płynąca z uczestnictwa w naturze Bożej.

\section{LA VOCATION DES LAICS Ã LA LUMIËRE DES ENONCÉS DU CONCILE VATICAN II}

\section{R E U M E}

L'auteur analyse, dans les constitutions "Gaudium et spes" et „Lumen gentium" ainsi que dans le décret sur l'apostolat des laïcs, les idées du concile concernant la vocation de ceux-ci. Après avoir donné la caractéristique de ce problème dans la théologie d'avant le concile, l'auteur concentre son attention sur la vocation au christianisme et sur les possibilités de rendre plus présente l'Eglise dans le monde par l'intermédiaire des membres laïes du peuple de Dieu. Dans la partie qui termint l'article, l'auteur étudie les relations entre, d'une part, la vocation des laiss dans l'Eglise et, d'autre part, la vocation au sacerdoce et à l'état religieux ainsi que la vocation particulière. 